\title{
Prinsip Good Environmental Governance oleh Pemerintah Kabupaten Siak (Studi Kasus Kebakaran Lahan Gambut Di Kecamatan Dayun)
}

\author{
${ }^{1}$ Sylvina Rusadi, ${ }^{2}$ Nina Yuslaini \\ 12 Universitas Islam Riau \\ email : sylvinarusadi@soc.uir.ac.id
}

\begin{abstract}
Abstrak
Negara Indonesia merupakan negara yang memiliki lahan gambut terbesar nomor empat di dunia.Untuk itu potensi kebakaran hutan dan lahan di Indonesia juga menjadi besar.Salah satu usaha yang dilakukan oleh pemerintah pusat dalam mencegah kebakaran hutan adalah dengan membuat aturan yang dapat menjadi dasar pedoman penanganan kebakaran lahan di Indonesia.Salah satu nya adalah melalui Peraturan Menteri Lingkungan Hidup dan Kehutanan Republik Indonesia Nomor 32 Tahun 2016 Tentang Pengendalian Kebakaran Hutan dan Lahan. Namun, hingga saat ini aturan yang ditetapkan belum dapat mencegah terjadinya kebakaran hutan dan lahan di Indonesia. Penelitian ini dilakukan di Provinsi Riau karena Provinsi Riau merupakan salah satu provinsi di Indonesia yang memiliki agenda tahunan bencana kebakaran hutan dan lahan. Penelitian ini bertujuan untuk mengetahui sejauh mana prinsip Good Environmental Governance dapat diterapkan oleh Pemerintah Kabupaten Siak dalam mencegah terjadinya kebakaran lahan dan juga untuk mengetahui faktor penghambat dalam penerapan Good Environmental Governance oleh Pemerintah Kabupaten Siak.Metode penelitian yang dilakukan adalah menggunakan metode Kualitatif melalui pendekatan studi kasus dengan menggunakan teori Good Environmental Governance dan menggunakan wawancara sebagai teknik pengumpulan data yang di ambil pada tahun 2019. Hasil penelitian diperoleh bahwa penerapan prinsip Good Environmental Governance oleh pemerintahan kabupaten siak dalam menanggulangi dan mencegah kebakaran lahan gambut sudah berjalan dengan baik.
\end{abstract}

Kata Kunci : Pemerintah daerah, Good Environmental Governance, Kebakaran,Lahan Gambut

\begin{abstract}
Indonesia is a country that has the fourth largest peatland in the world. For this reason, the potential for forest and land fires in Indonesia is also large. One of the efforts made by the central government to prevent forest fires is by making regulations that can become the basis for guidelines for handling fires. one of them is through the Regulation of the Minister of Environment and Forestry of the Republic of Indonesia Number 32 of 2016 concerning Control of Forest and Land Fires. However, until now the stipulated regulations have not been able to prevent forest and land fires in Indonesia. This research was conducted in Riau Province because Riau Province is one of the provinces in Indonesia which has an annual agenda for forest and land fire disasters. This study aims to determine the extent to which the principles of Good Environmental Governance can be applied by the Siak Regency Government in preventing land fires and also to determine the inhibiting factors in the implementation of Good Environmental Governance by the Siak Regency Government. The research methodology used is a qualitative method through a case study approach. by using the theory of Good Environmental Governance and using interviews as a data collection technique taken in 2019. The results showed that the application of the principles of Good Environmental Governance by the Siak district government in overcoming and preventing peatland fires had gone well.
\end{abstract}

Keywords: Local government, Good Environmental Governance, Fire, Peatlands 


\section{PENDAHULUAN}

Berdasarkan data Wetland Internasional tahun 2019, negara Indonesia berada pada urutan kedua dalam kepemilikan lahan gambut di dunia yakni sebesar 22,5 juta ha. Potensi lahan gambut yang sangat besar ini menyebabkan negara Indonesia memiliki potensi lahan yang subur.Namun sebaliknya pada kondisi kemarau lahan gambut memiliki resiko tinggi kebakaran yang disebabkan oleh keringnya kondisi tanah yang mencapai kedalaman hingga 10 meter, sehingga kebakaran di lahan ini sulit untuk dipadamkan.Salah satu usaha yang dilakukan oleh pemerintah pusat dalam mencegah kebakaran hutan adalah dengan jalan membuat suatu aturan yang dapat menjadi dasar pedoman penanganan kebakaran lahan yang terjadi di Indonesia.Salah satu nya adalah melalui Peraturan Menteri Lingkungan Hidup dan Kehutanan Republik Indonesia Nomor 32 Tahun 2016 Tentang Pengendalian Kebakaran Hutan dan Lahan.Namun sejak dikeluarkannya aturan tersebut hingga sekarang permasalahan kebakaran lahan belum dapat terselesaikan secara optimal.

Sebagai salah satu Provinsi yang memiliki catatan buruk terhadap kebakaran hutan dan lahan, provinsi Riau perlu melakukan upaya-upaya dalam pencegahan sedini mungkin. Untuk melihat lebih jelas mengenai potensi titik api yang terjadi di provinsi Riau setiap tahunnya dapat dilihat pada tabel di bawah ini:

Tabel I.1 Titik api di Provinsi Riau

\begin{tabular}{ccc}
\hline No & Tahun & Jumlah Titik Api \\
\hline 1 & 2015 & 183.808 \\
\hline 2 & 2016 & 85.219 \\
\hline 3 & 2017 & 6.866 \\
\hline 4 & 2018 & 37.220 \\
\hline 5 & 2019 & 90.550 \\
\hline
\end{tabular}

\section{Sumber : Kementrian Lingkungan Hidup, 2019}

Jika diperhatikan secara seksama data dari Kementrian Lingkungan Hidup menunjukkan bahwa kondisi kebakaran lahan gambut di Provinsi Riau mengalami penurunan jika dibandingkan dengan tahun 2015 yang menjadi tahun-tahun buruk sepanjang bencana kebakaran lahan di provinsi Riau yakni sebanyak 183.808 titik panas. Dan untuk tahun 2016 sebanyak 85.219 titik panas, tahun 2017 sebanyak 6.866, tahun 2018 sebanyak 37.220 titik panas dan untuk tahun 2019 memiliki 90.550 titik panas yang tersebar luas di Kabupaten Siak, Kabupaten Pelalawan, Kabupaten Bengkalis, Kabupaten Rokan Hilir, Kabupaten Kuantan Singingi, Kabupaten Kampar serta Kota Dumai. Dan dalam hal ini yang menjadi fokus lokasi penelitian yang penulis ambil adalah pada Kabupaten Siak dengan mengambil lokasi Kecamatan Dayun sebagai salah satu titik panas terbanyak di Kabupaten Siak.

Penelitian ini sangat penting untuk diteliti karena kebakaran hutan dan lahan yang berkepanjangan dapat mengganggu kesehatan masyarakat yakni ISPA (Infeksi Saluran Pernapasan Akut) yang sangat berbahaya terutama bagi anak dan balita.Kebakaran ini juga dapat mengganggu potret pendidikan, karena sekolah banyak yang diliburkan.

Good Environmental Governance merupakan salah satu prinsip yang menjelaskan tentang melihat kemampuan pemerintah dalam mengelola kemampuannya yang dihubungkan dengan lingkungan hidup. Untuk itu, prinsip Good Environmental Governance dapat dijadikan sebagai salah satu upaya dalam pencegahan kebakaran hutan dan lahan dengan cara pengaplikasian setiap indikator-indikator yang ada didalamnya.

Tujuan khusus penelitian ini adalah ingin melihat dan mengukur keberhasilan konsep Good Environmental Governance apabila digunakan untuk menangani permasalahan kebakaran hutan dan lahan di kabupaten Siak.Dan juga ingin melihat faktor-faktor penghambat dalam penanganan kebakaran hutan dan lahan yang terjadi di Kabupaten Siak. 


\section{METODE}

Metode yang digunakan pada penelitian ini adalah menggunakan metode kualitatif dengan tipe penelitian studi kasus, yakni melakukan penelitian sebagai bentuk tindak lanjut dari keajdian atau kasus yang telah terjadi dengan tujuan ingin menemukan solusi-solusi dari permasalahan tersebut. Adapun langkah-langkah yang dilakukan dalam menganalisis adalah :

1. Reduksi data merupakan langkah awal yang dilakukan yang bertujuan untuk mengelompokkan dan menyederhanakan kemudian membuang data-data yang kurang relevan agar lebih mudah untuk digunakan.

2. Penyajian data merupakan sebuah langkah yang dilakukan dengan mengumpulkan data secara berututan dan runtut agar mudah untuk ditarik suatu kesimpulan.

3. Kesimpulan merupakan tahapan akhir yang dilakukan dengan menganalisis data yang telah diperoleh sehingga terjawablah tujun penelitian yang hendak di capai.

\section{HASIL DANPEMBAHASAN}

Hasil penelitian mengenai prinsip Good Environmental Governance oleh Pemerintah Kabupaten Siak (Studi Kasus Kebakaran Lahan Gambut Di Kecamatan Dayun) diperoleh melalui proses pengumpulan datadata yang dilakukan melalui wawancara dengan informen kunci yakni Kepala Badan Penanggulangan Bencana Kabupaten Siak serta informen tambahan yakni Camat Dayun sebagai lokus penelitian. Daftar pertanyaan wawancara bersumber dari indikator penelitian yang peneliti dapatkan melalui jurnal Belbase (2018) yang menyatakan bahwa ada 7 (tujuh) prinsip dalam menilai Good Environmental Governance yakni:

\section{Aturan hukum (the rule of law)}

Aturan hukum (the rule of law) merupakan suatu alat yang digunakan negara untuk mengatur warganya. Hal ini dianggap penting karena dengan adanya aturan pemerintah dapat dengan mudah menggunakan kewenangannya. Penegakan hukum merupakan masalah yang penting untuk dilakukan seperti halnya dalam permasalahan kebakaran hutan yang pada akhir tahun 2019 menjadi masalah yang terus berulang di setiap kabupaten di Provinsi Riau khususnya pada Kabupaten Siak.

Berdasarkan wawancara yang peneliti lakukan dengan Badan Penanggulangan Bencana Daerah Kabupaten Siak yang diwaliki oleh sekretaris badan mengatakan bahwa dalam menjalankan tugas tentunya sangat penting untuk mengikuti aturan hukum yang berlaku khususnya mengenai kebakaran lahan ini karena aturan yang dibuat tentu sudah melali uji coba dan tinggal dilaksanakan saja. Adapun yang menjadi landasan aturan hukum itu yakni melalui Peraturan Daerah Provinsi Riau Nomor 1 Tahun 2019 Tentang Pedoman Teknis Penanggulangan Kebakaran Hutan Dan/Atau Lahan.

Berdasarkan analisis peneliti aturan hukum sangat lah penting untuk dijadikan suatu pijakan bagi pemerintah dalam melakukan segala tindakan yang berkaitan dengan kewenangan yang akan dijalankannya. Dan aturan hukum juga mengandung suatu keaturan mengenai sesuatu yang boleh dan tak boleh dilakukan, serta memiliki sanksi hukum yang jelas. Ada beberapa hal yang menjadi faktor belum tegaknya prinsipprinsip negara hukum Indonesia yakni (Usman, 2014) :

a. kurang mengetahui adanya ketentuan hukum dan kurang memahami hukum

b. cenderung kurang menghargai dan mempercayai proses penegakan hukum yang sedang berlangsung

c. faktor integritas dan moral yang rendah 
d. faktor sarana dan prasarana yang belum memadai Untuk itu penting kiranya untuk menjadi perhatian bersama mengenai kesadaran hukum baik bagi masyarakat maupun bagi pemerintah itu sendiri agar fungsi aturan dapat terwujud dengan baik.

\section{Partisipasi dan Representasi (participation and representation)}

Partisipasi dan Representasi (participation and representation) merupakan suatu bentuk keikutsertaan seorang individu ataupun kelompok dalam melakukan suatu tindakan baik secara langsung maupun tidak langsung dalam pencapaian tujuan secara bersama.Partisipasi adalah wujud dari keinginan untuk mengembangkan demokrsi melalui proses desentralisasi dimana diupayakan antara lain perlunya perencanaan dari bawah dengan mengikutsertakan masyarakat dalam proses perencanaan dan pembangunan masyarakatnya. (Tilaar, 2009)

Berdasarkan wawancara yang peneliti lakukan bersama Sekretaris Badan Penanggulangan Bencana Daerah Kabupaten Siak diketahui bahwa dalam penanganan kebakaran lahan masyarakat dan pihak swasta ikut turut serta membantu tugas Badan Penanggulangan Bencana Daerah, baik berupa tenaga maupun bantuan berupa materil. Kelompok masyarakat ini dinamakan masyarakat peduli api yang dibentuk di setiap kecamatan yang ada di Kabupaten Siak. Hal ini sangat membantu meringankan tugas BPBD mengingat luasnya lahan yang mengalami kebakaran.

Berdasarkan analisis peneliti partisipasi yang diperoleh dari masyarakat maupun pihak swasta merupakan suatu bentuk kerjasama yang dapat memecahkan persoalan yang terjadi. Partisipasi yang terjalin antara pemerintah dan masyarakat merupakan suatu bentuk kesadaran masyarakat tentang rasa tanggungjawabnya terhadap rusaknya lingkungan sekitar.

\section{Akses terhadap informasi (access to information)}

Akses terhadap informasi (access to information), merupakan jalan masuk atau perantara dalam menerima ataupun memberikan informasi kepada publik. Akses informasi sagat penting untuk ditingkatkan agar penanganan permasalahan kebakaran lahan gambut dapat dengan mudah diselesaikan.

Berdasarkan wawancara yang dilakukan dengan Camat Dayun bahwa untuk akses informasi yang diberikan oleh pihk kecamatan kepada masyarakat maupun kepada Badan Penanggulangan Bencana Daerah sangat jelas, mulai dari sumber kebakaran,jenis lahan yang terbakar hingga penyebab kebakaran itu sendiri. Begitu pula dengan wawancara yang dilakukan dengan Sekretaris Badan Penenggulangan Bencan Daerah Kabupaten Siak yang mengatakan sejauh ini untuk informasi yang diterima dan diberikan kepada dan dari masyarakat sangat jelas karena hal ini sangat penting untuk dilakukan agar penanganan serta pencegahan kebakaran lahan dapat berjalan efektif dan efisien. Bentuk informsi yang diberikan adalah melalui media masa maupun elektronik.

Analisis peneliti terhadap akses informasi mengenai lahan gambut ini sangat penting agar penanganan kebakaran lebih tepat sasaran, peran Badan Penanggulangan Bencana Daerah Kabupaten Siak maupun Kecamatan Dayun sejauh ini sudah dapat dikatakan baik dalam memberikan akses informasi nbagi masyarakat yang membutuhkan.

\section{Transparansi dan akuntabilitas (transparency and accountability)}

Transparansi merupakan keterbukaan pemerintah dalam memberikan informasi yang terkait dengan aktivitas pengelolaan sumber daya publik kepada pihak-pihak yang membutuhkan informasi. Sedangkan akuntabilitas merupakan bentuk kewajiban mempertanggungjawabkan keberhasilan atau kegagalan, pelaksanaan misi organisasi dalam mencapai tujuan dan sasaran yang telah ditetapkan sebelumnya, melalui surat media pertanggungjawaban secara periodik. (Mardiasmo, 2006)

Berdasarkan hasil wawancara diperoleh bahwa transparansi dan akuntabilitas dalam penanggulangan kebakaran lahan gambut di kabupaten Siak telah berjalan dengan baik hal ini ditandai dengan adanya 
keterbukaan akses informsi yang dapat di akses oleh publik mengenai titik api serta penanganan kebakaran lahan.

Berdasarkan analisis peneliti transparansi dan akuntabilitas sangat penting untuk dijalankan oleh pemerintah karena kedua prinsip ini menyangkut rasa kepercayaan masyarakat terhadap pemerintah dalam menjalankan fungsi-fungsinya.Dan apabila kedua hal ini tidak dilakukan maka masyarakat tidak akan percaya lagi dengan pemerintah.

\section{Desentralisasi (decentralitation)}

Desentralisasi merupakan penyerahan kekuasaan pemerintahan oleh pemerintah pusat kepada daerah otonom berdasarkan asas otonomi. Berdasarkan wawancara yang dilakukan pada dasarnya permasalahan kebakaran lahan gambut yang terjadi di Kabupaten Siak merupakan kewenangan dari daerah untuk menyelesaikan.Namun apabila daerah bencana tidak dapat menyelesaikan maka pusat akan mengambil alih dan dijadikan status bencana menjadi bencana nasional. Untuk itu pemerintah daerah perlu mengerahkan segala kemampuan yang dimiliki untuk dapat menyelesaikan permasalahan kebakaran yang sudah menjadi bencana tahunan di provinsi Riau dan Kabupaten Siak khususnya.

Berdasarkan analisis yang peneliti lakukan maka desentralisasi dalam penyelesaian permasalahan kebakaran lahan di kabupaten Siak sudah dapat dikatakan sesuai dengan kewenangan yang diberikan. Kewenangan ini juga dapat diambil kembali oleh pusat apabila daerah tidak mampu menjalankannya. Hal ini menjadi penting untuk diperhatikan karena bencana kebakaran lahan yang menyebabkan kabut asap memiliki dampak yang sangat buruk bagi keberlangsungan kehidupan msayarakat mulai dari kesehata,pendidikan dan ekonomi.

\section{Lembaga dan institusi (institutions and agencies)}

Lembaga dan insitusi merupakan organisasi perangkat daerah yang ditunjuk untuk menjalankan kewenangan sesuai dengan tugas pokok dan fungsinya yang diatur melalui perundangundangan.Berdasarkan wawancara yang dilakukan maka dapat diketahui bahwa organisasi perangkat daerah yang bertanggungjawab terhadap kebakaran lahan gambut di kabupaten Siak adalah Badan Penanggulangan Bencana Daerah pada Kepala Sub Bidang Pemadam Kebakaran. Namun tidak menutup kemungkinan adanya pihak-pihak lain yang ikut membantu yakni gabungan personil Tentara Nasional Indonesia, Polisi Republik Indonesia, masyarakat hingga pihak swasta.

Berdasarkan analisis yang peneliti lakukan dapat diketahui bahwa Badan Penanggulangan Bencana Daerah Kabupaten Siak sudah sesuai dengan penunjukan tugas dan fungsi melalui Peraturan Daerah Kabupaten Siak nomor 15 Tahun 2012.

\section{Akses untuk memperoleh keadilan ( access for justice)}

Akses untuk memperoleh keadilan merupakan suatu jalan yang dapat diperoleh oleh seorang individu ataupun kelompok untuk mendapatkan hak berupa keadilan.Berdasarkan wawancara yang peneliti lakukan untuk ases dalam memperoleh keadilan dalam penanganan kebakaran lahan gambut di Kabupaten Siak dibuka selbar-lebarnya. Dalam hal ini keadilan yang dimaksud adalah hak warga negara untuk dapat menikmati udara yang segar tanpa dicemari oleh kabut asap akibat kebakaran lahan. Untuk itu jika memang penyebab kebakaran ini adalah adanya perusahaan atau bahkan warga masyarakat yang membuka lahan, maka akan ditindak lanjuti sesuai dengan aturan yang berlaku sebagai bentuk efek jera agar kedepannya tidak terjadi lagi.

Berdasarkan analisis dan observasi yang peneliiti lakukan keadilan sudah ditegakkan, hal ini terbukti dengan sudah ditangkapnya masyarakat maupun pemilik perusahaan yang telah menjadi penyebab kebakaran lahan gambut di Kabupaten Siak. Dari proses wawancara dan observasi yang peneliti lakukan maka prinsip Good environmental governance oleh Pemerintah Kabupaten Siak (Studi Kasus Kebakaran 
Lahan Gambut Di Kecamatan Dayun) pada dasarnya telah berjalan dengan baik hal ini dibuktikan dari 7 (tujuh) prinsip yang diuji maka ketujuh prinsip tersebut telah dijalankan dengan baik oleh pemerintah Kabupaten Siak. Hal ini memiliki dampak positif bagi pemerintah yang dengan diberlakukannya prinsip Good environmental governance berarti pemerintah Kabupaten Siak sudah memiliki tata kelola pemerintahan yang baik dalam memperhatikan limgkungan. Adapun faktor penghambat dalam penelitian ini adalah kurangnya sarana prasarana yang dimiliki oleh pemerintah Kabupaten Siak seperti armada mobil pemadam, ketersediaan lumbung air dan terlebih jika area kebakaran luas maka untuk memadamkan kebakaran pemerintah membutuhkan helikopter pemadam api.

\section{KESIMPULAN}

Dari penelitian dengan metode kualitatif yang peneliti lakukan maka dapat diketahui pada dasarnya penerapan prinsip Good Environmental Governance oleh pemerintah kabupaten Siak sudah berjalan dengan baik. Hal ini ditandai dengan terlaksananya ketujuh indikator dari Good Environmental Governancemenurut Belbase. Dan untuk faktor penghambat dari penerapan prinsip ini adalah adanya kekurangan sarana dan prasarana dalam memadamkan lahan gambut yang terbakar.

\section{DAFTAR PUSTAKA}

[1]. Arifudin. A et al.,(2019) "Dinamika Penggunaan, Kebakaran, dan Upaya Restorasi Lahan Gambut: Studi Kasus di Desa Tanjung Leban, Bengkalis," Seminar Nasional Pembangunan Pertanian dan Perdesaan, Volume 1.

[2]. Belbase. N (2010) “Environmental Good Governance In The Future Constitution In Nepal,” IUCN Nepal, Volume 1.

[3]. Candrakirana. R. (2015) "Penegakan Hukum Lingkungan Dalam Bidang Pengelolaan Sampah Sebagai Perwujudan Prinsip Good Environmental Governance di Kota Surakarta” Yustisia Jurnal Hukum Volume 4(3)

[4]. Erlina. N (2017) "Analisis Pembangunan Canal Blocking sebagai Solusi Pencegahan Kebakaran Lahan Gambut di Desa Sungai Tohor Kabupaten Kepulauan Meranti" Jurnal Online Mahasiswa Fisip Universitas Riau, Volume 4(2)

[5]. Feris. L (2010) “The Role of Good Environmental Governance in the Sustainable Development of South Africa," Potchefstroom Electron Law Journal Volume 13(1)

[6]. Mardiasmo (2006) "Perwujudan Transparansi dan Akuntabilitas Publik Melalui Akutansi Sektor Publik; Suatu Sarana Good Goivernance” Jurnal Akutansi Pemerintah.Volume 2(1)

[7]. Mulyono P (2018) "Good Environmental Governance through the Inovation of Solid Waste Management in the Community of Gili Ketapang Island Kabupaten Probolinggo” KnE Social Sciences Volume 2018 
[8]. Paavola. J (2007) "Institutions and environmental governance: A reconceptualization" Journal Ecological Economics Volume 63(1)

[9]. Prianto A.L dan Faisah N (2015) “ Good Environmental Governance (Studi Kasus Penegelolaan Taman Macan Di Kota Makassar)” Jurnal Otoritas Volume 5(2)

[10]. Sawerah. S, Muljono. P dan Tjitropranoto (2017) "Partisipasi Masyarakat dalam Pencegahan Kebakaran Lahan Gambut di Kabupaten Mempawah, Provinsi Kalimantan Barat," Jurnal Penyuluhan Volume 12(1)

[11]. Setiawan A (2018) "Kebijakan Penanganan Kebakaran Hutan dan Lahan di Indonesia" Journal of Political Ecology

[12]. Taplin. R (2012) "People, Policy and Politics in Future Climates," in The Future of the World's Climate

[13]. Techera.E.J (2011) “Good Environmental Governance: Overcoming Fragmentation in International Law for Shark Conservation and Management," Proc. ASIL Annu. Meet

[14]. Tilaar.H.A.R (2009) "Kekuasaan dan Pendidikan : Kajian Manajemen Pendidikan Nasional dalam Pusaran Kekuasaan.” Jakarta: Rineka cipta

[15]. Usman.A.H. (2014) "Kesadaran Hukum Masyarakat dan Pemerintah Sebagai Faktor Tegaknya Negara Hukum di Indonesia” Jurnal Wawasan Hukum Volume 30(1) 